\title{
Disturbed virus-bacteria dynamics in Otsuchi Bay (Japan) after the mega-earthquake and tsunami in March 2011
}

\author{
Toshi Nagata ${ }^{1, *}$, Yanhui Yang $^{1}$, Hideki Fukuda ${ }^{2}$ \\ ${ }^{1}$ Atmosphere and Ocean Research Institute, The University of Tokyo, 5-1-5 Kashiwanoha, Kashiwa, Chiba 277-8564, Japan \\ ${ }^{2}$ International Coastal Research Center, Atmosphere and Ocean Research Institute, The University of Tokyo, 1-19-8 Akahama, \\ Otsuchi, Iwate 028-1102, Japan
}

\begin{abstract}
On 11 March 2011, a mega-earthquake followed by a huge tsunami hit a large area of the Pacific coast of Tohoku, Japan, and caused widespread disturbances in marine ecosystems; however, the impacts on virus-bacteria systems have not yet been elucidated. To investigate whether virus-bacteria interactions were affected by the earthquake and tsunami, we analyzed time series data of viral and bacterial abundances in Otsuchi Bay. Data were collected every 2 mo, from July 2011 to September 2015. Bacterial abundance exhibited a recurrent seasonal cycle with high abundance during the warm season. The seasonal trend of viruses generally followed that of the bacteria, yielding an average virus to bacteria ratio (VBR) of $10.8 \pm 3.6$ (mean $\pm \mathrm{SD} ; \mathrm{n}=432$ ). A notable exception was found at the first 2 sampling times (July and September 2011) when the VBR was consistently low, with an average value of $5.9 \pm 1.2(\mathrm{n}=32)$. The average VBR during these time periods was substantially lower than the VBR observed in the same season of subsequent years. An analysis of the subset of data collected in the warm season of 2011 and 2012 revealed that the viral abundance and VBR were negatively correlated with turbidity. These results support the hypothesis that viruses were scavenged by non-host particles from the resuspended sediments and damaged catchment. The earthquake and tsunami thus exerted a prolonged impact, over several months, on the virus-bacteria dynamics in Otsuchi Bay.
\end{abstract}

KEY WORDS: Virus - Bacteria - Virus to bacteria ratio - Tsunami - Earthquake - Turbidity · Otsuchi Bay · Coastal marine environments

\section{INTRODUCTION}

On 11 March 2011, a large area of the Pacific coast of Tohoku, Japan, was hit by a mega-earthquake followed by a huge tsunami (Goto et al. 2021). The tsunami exerted significant effects on benthic communities, including primary producers (Komatsu et al. 2015, Hamaoka et al. 2020) and consumers (Seike et al. 2013, Muraoka et al. 2017). In contrast, the impact on pelagic communities, including phytoplankton and zooplankton, was generally smaller, presumably due to the high growth and dispersion of planktonic organisms (Nishibe et al. 2016, Tachibana

${ }^{*}$ Corresponding author: nagata@aori.u-tokyo.ac.jp et al. 2017). Impacts of the earthquake and tsunami on the ecological dynamics of microbes and viruses in the damaged area have yet to be explored. As viral infection of microbes is critical for regulating the trophic transfer and nutrient cycling in marine ecosystems (Suttle 2007, Zimmerman et al. 2020), examination of the virus-bacteria dynamics is essential to fully determine the effects of the tsunami on coastal ecosystems in the devastated area.

Here we examined the viral and bacterial abundances as well as the virus to bacteria ratio (VBR) in the damaged area. VBR varies greatly across aquatic habitats (Parikka et al. 2017) and in marine environ-

() The authors 2022. Open Access under Creative Commons by Attribution Licence. Use, distribution and reproduction are unrestricted. Authors and original publication must be credited. 
ments (Wigington et al. 2016, Finke et al. 2017), being controlled by a multitude of biological and environmental factors in a complex manner. Previous studies have examined seasonal and interannual variabilities of viral abundance and VBR in coastal marine environments (Li \& Dickie 2001, Winget et al. 2011). However, to our knowledge, no studies have examined the responses of virus-bacteria systems to environmental perturbations caused by large earthquakes and tsunamis.

Data were collected in Otsuchi Bay, a semi-closed embayment, with major and minor axis lengths of 7 and $3 \mathrm{~km}$, respectively. The tsunami reached a maximum height of $15.1 \mathrm{~m}$, caused large disturbances to the bottom sediments, destroyed 5600 buildings in the inundated area $\left(6.68 \mathrm{~km}^{2}\right)$, and generated $612 \times 10^{3} \mathrm{t}$ of debris (Fukuda et al. 2015). Seawater sampling was carried out approximately every 2 mo from July 2011 (4 mo after the occurrence of the tsunami) to September 2015. As we could not find any data that were collected either before or immediately after the tsunami,

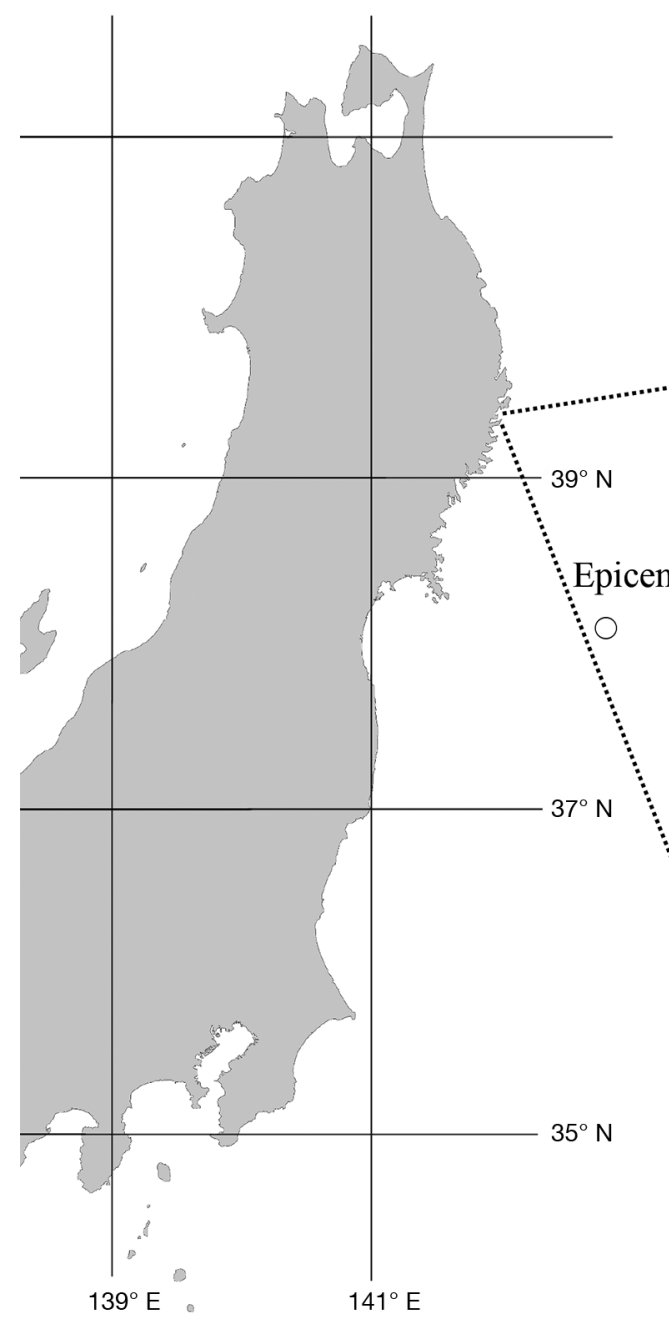

Fig. 1. Sampling stations in Otsuchi Bay, Japan. The epicenter of the mega-earthquake on 11 March 2011 is marked by an open circle in the left panel we were unable to assess the acute impacts of the earthquake and tsunami on the virus-bacteria systems. Therefore, we examined whether the tsunami exerted any prolonged (monthly time scale) impact on the surrounding area. In the bay, environmental conditions were monitored starting in May 2011 (Fukuda et al. 2015, 2017). Fukuda et al. (2015) observed high turbidity in the bay until at least the fall of 2011 (about 6 mo after the tsunami). The prolonged high turbidity in the bay was likely due to the sediment resuspension caused by the earthquake aftershocks and the loading of particulate materials released from tsunami debris and reconstruction activities (Ikehara et al. 2014, Fukuda et al. 2015).

\section{MATERIALS AND METHODS}

\subsection{Sampling stations and temperature and salinity measurements}

Water-column samples were collected using a 121 Niskin bottle (General Oceanics) at 5 stations in Otsuchi Bay, Japan (Fig. 1). The bottom depth at each station ranged from 8 to $80 \mathrm{~m}$. Depending on the bottom depth, samples were collected from 3 to 5 depths including the surface (1 $\mathrm{m}$ depth) and bottom (approximately $1 \mathrm{~m}$ above the bottom) layers. The samples were typically collected every 2 mo from July 2011 to 
September 2015, although sampling was intermittent at some stations (Table S1 in the Supplement at www.int-res.com/articles/suppl/a088p031_supp.pdf). In Section 3, the data collected at 2 sampling stations, Stn 2 (located at the center of the bay) and Stn 16 (near the river mouth), are presented in the main text (Figs. 2 \& 3), whereas the data from other stations are in the Supplement (Figs. S1-S3). Temperature and salinity were measured using conductivity-temperaturedepth sensors (ACL2180-TPM, Alec Electronics; ASTD687 or ASTD102, JFE Advantech). Data on the nutrients, chlorophyll $a(\mathrm{chl} a)$, and turbidity collected at the same stations, between May 2011 and March 2016, have been published elsewhere (Fukuda et al. 2015 , 2017). However, turbidity data are only available for the period between May 2011 and November 2012 (Fukuda et al. 2015).

\subsection{Abundances of bacteria, viruses, and pico- and nanophytoplankton}

Seawater samples ( $2 \mathrm{ml}$ each) were fixed with glutaraldehyde $(20 \%$ solution for electron microscopy, FUJIFILM Wako Pure Chemical), at a final concentration of $1 \%$, for $15 \mathrm{~min}$ in the dark. The glutaraldehyde solution was prefiltered through $0.02 \mu \mathrm{m}$ pore size inorganic membrane filters (Anotop ${ }^{\mathrm{TM}} 25$, Whatman). The samples were flash frozen in liquid nitrogen and stored at $-80^{\circ} \mathrm{C}$ until further analysis. Bacteria, viruses, and pico- and nano-phytoplankton were counted using flow cytometry (Marie et al. 1999, Brussaard 2004, Yang et al. 2010). After thawing, the bacterial and viral samples were diluted with Trisethylenediaminetetraacetic acid (EDTA) buffer 10 and 100 times, respectively $(10 \mathrm{mM}$ Tris-hydrogen chloride, 1 mM EDTA, pH 8.0; Nippon Gene; prefiltered through $0.02 \mu \mathrm{m}$ pore size inorganic membrane filters, Anotop ${ }^{\mathrm{TM}} 25$; Whatman). The samples were then stained with SYBR Green I (Molecular Probes) at final concentrations of $10^{-4}$ and $5 \times 10^{-5}$ for bacteria and viruses, respectively. After incubation at room temperature for $15-30 \mathrm{~min}$ (for bacteria) or at $80^{\circ} \mathrm{C}$ for $10 \mathrm{~min}$ (for viruses), $1 \mu \mathrm{m}$ yellow-green beads (Molecular Probes) were added to the samples as the internal standards. The samples were then injected into the flow cytometer (FACS Calibur; Becton Dickinson). The flow cytometric method may underestimate viral abundance because it primarily counts double-stranded DNA viruses and may fail to detect DNA and RNA viruses with small genomes (Tomaru \& Nagasaki 2007, Steward et al. 2013). Picoand nanophytoplankton abundances were counted without staining. Picocyanobacteria, picoeukaryotes, and cryptophytes (nanoplankton) were discriminated based on the relative strength of the orange (phycoerythrin) and red (chlorophyll) fluorescence that they exhibited (Marie et al. 2014). Prior to injection, the samples with high turbidity or with dense phytoplankton cells were pre-filtered through $35 \mu \mathrm{m}$ nylon mesh using Falcon cell strainers (Becton Dickinson) to avoid clogging. The obtained data were analyzed using CellQuest software (Becton Dickinson).

\subsection{Statistics}

SigmaPlot v.14.4 (Systat Software) was used for non-parametric statistical analysis (Spearman's correlation) and to test for differences (Kruskal-Wallis 1-way ANOVA on ranks with Dunn's test [ANOVA on ranks]) between the biotic and environmental variables. The same software was used to conduct linear and quadratic regression analyses and to generate histograms and dot plots.

\section{RESULTS AND DISCUSSION}

\subsection{General hydrographic features}

Seawater temperature ranged from $3.6-23.2^{\circ} \mathrm{C}$, with a maximum in September for each year

Table 1. Summary of the environmental and biological data collected between July 2011 and December 2014 in Otsuchi Bay, Japan. $\mathrm{n}=432$ unless otherwise indicated. VBR: virus to bacteria ratio.

\begin{tabular}{|c|c|c|c|}
\hline Variable & Range & Mean & SD \\
\hline Temperature $\left({ }^{\circ} \mathrm{C}\right)$ & $3.6-23.2$ & 13.7 & 5.1 \\
\hline Salinity & $27.2-34.0$ & 33.2 & 1.0 \\
\hline Sigma t & $18.7-26.5$ & 24.8 & 1.4 \\
\hline Chl a concentration $\left(\mu g l^{-1}\right)^{a}$ & $0.1-39$ & 2.2 & 3.6 \\
\hline $\begin{array}{l}\text { Picocyanobacterial } \\
\text { abundance }\left(10^{3} \text { cells } \mathrm{ml}^{-1}\right)\end{array}$ & $0.3-240$ & 37 & 52 \\
\hline $\begin{array}{l}\text { Picoeukaryote } \\
\text { abundance }\left(10^{3} \text { cells } \mathrm{ml}^{-1}\right)\end{array}$ & $1.7-140$ & 21 & 22 \\
\hline $\begin{array}{l}\text { Cryptophyte abundance } \\
\left(10^{3} \text { cells } \mathrm{ml}^{-1}\right)\end{array}$ & $0.0-4.5$ & 0.3 & 0.5 \\
\hline $\begin{array}{l}\text { Bacterial abundance } \\
\left(10^{5} \text { cells } \mathrm{ml}^{-1}\right)\end{array}$ & $3.4-46$ & 18 & 9.5 \\
\hline $\begin{array}{l}\text { Viral abundance } \\
\left(10^{7} \text { viruses } \mathrm{ml}^{-1}\right)\end{array}$ & $0.5-4.0$ & 1.8 & 0.9 \\
\hline VBR & $3.8-23.5$ & 10.8 & 3.6 \\
\hline${ }^{\mathrm{a}} \mathrm{n}=416$ & & & \\
\hline
\end{tabular}



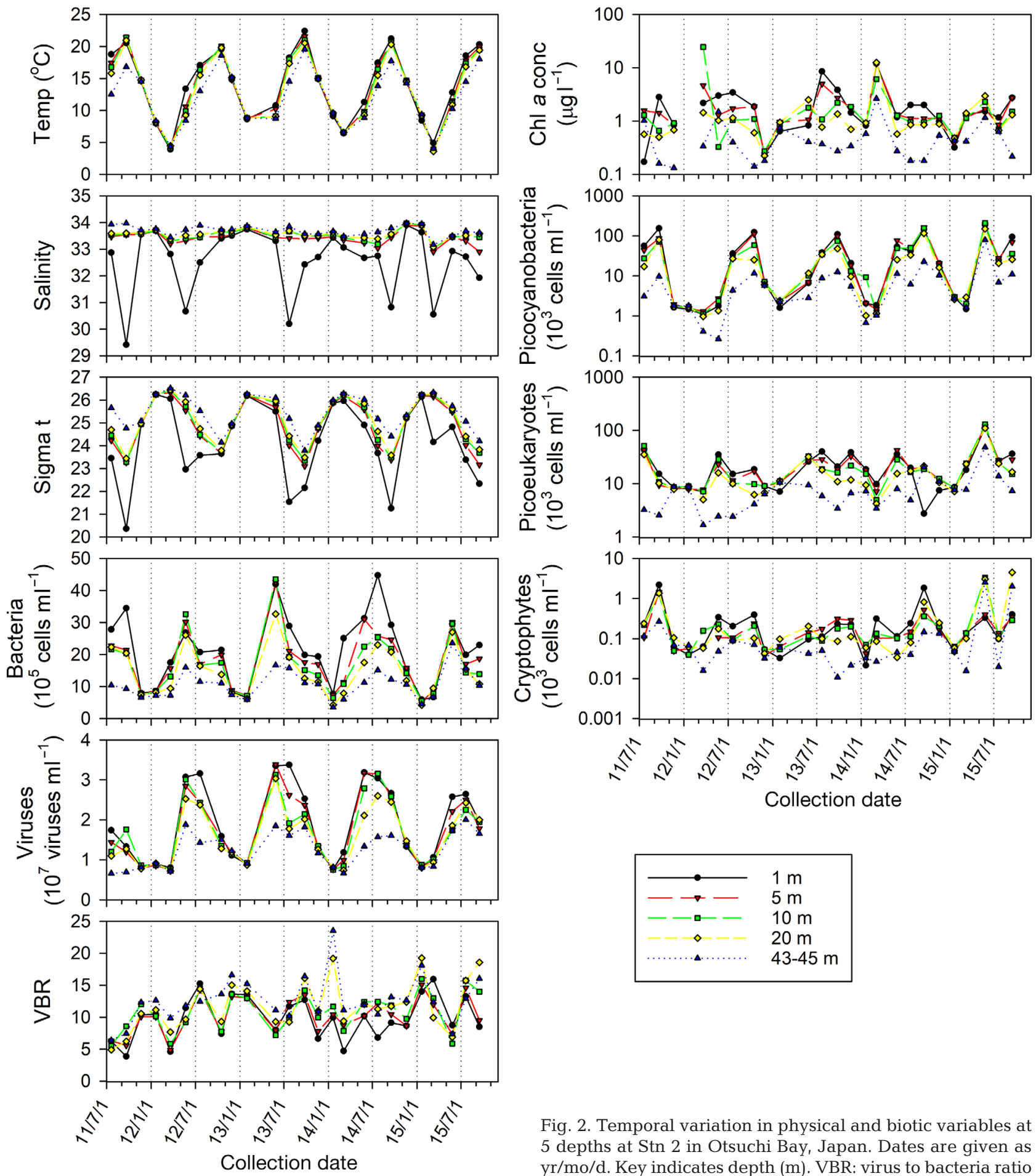

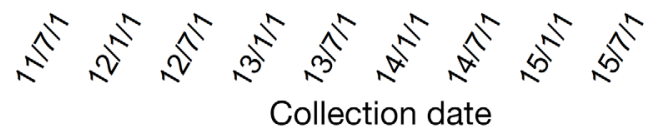

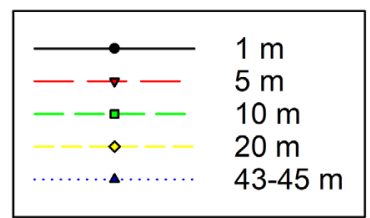

Fig. 2. Temporal variation in physical and biotic variables at 5 depths at Stn 2 in Otsuchi Bay, Japan. Dates are given as $\mathrm{yr} / \mathrm{mo} / \mathrm{d}$. Key indicates depth (m). VBR: virus to bacteria ratio

(Table 1, Figs. $2 \&$ \&; Figs. S1-S3). During the warm season, a shallow pycnocline (1-5 m depth) was established due to the influence of freshwater discharge. The water column was stratified, with low-salinity water in the surface layer (mean salinity $=31.5$; range: $27.2-33.4$ ). This surface seawater

overlaid the saltier seawater originating from the Tsugaru Warm Current; the mean salinity at depths of $>5$ m was 33.5 (range: $32.8-34.0$ ). Watercolumn mixing proceeded from fall to winter due to surface cooling and reduced river discharge. From January to March, Oyashio water intruded 

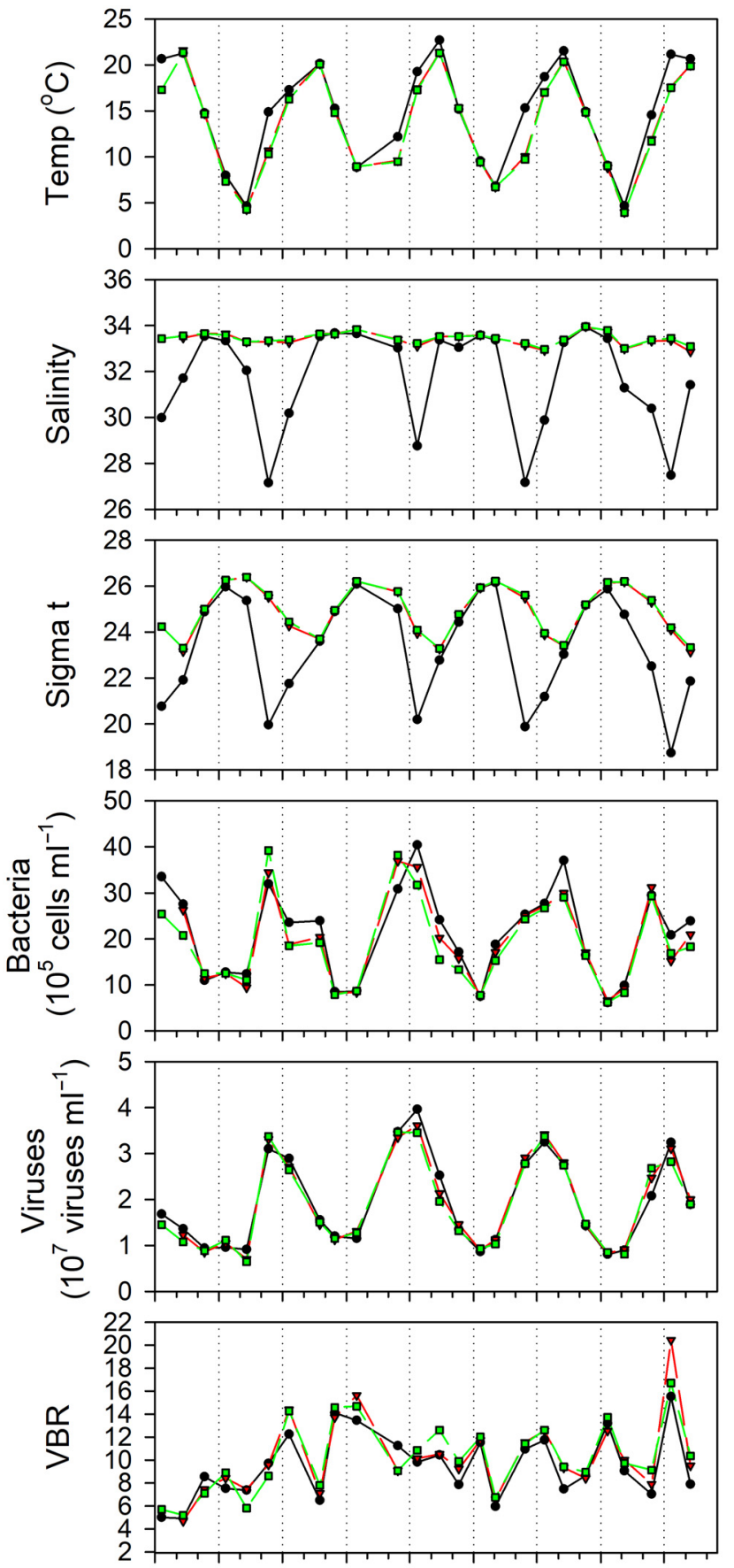

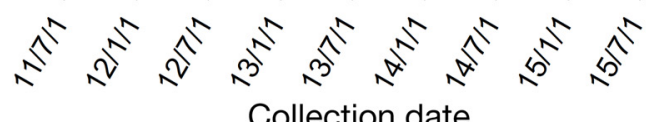

into the bay (Ishizu et al. 2017). During this period, the mean temperature and salinity were $7.3^{\circ} \mathrm{C}$ (range: $3.6-9.6^{\circ} \mathrm{C}$ ) and 33.5 (range: $30.6-34.0$ ), respectively. These hydrographic features are consistent with the results of previous studies (Otobe et al. 2009, Ishizu et al. 2017).

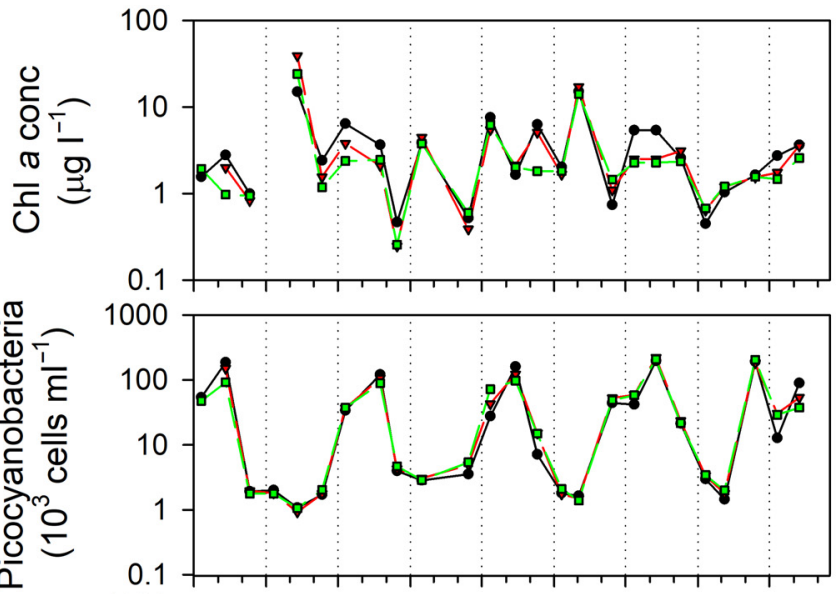

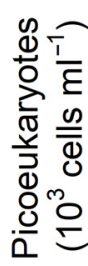
1000

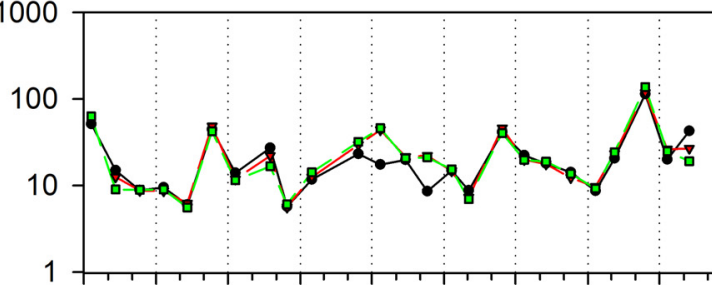

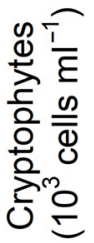
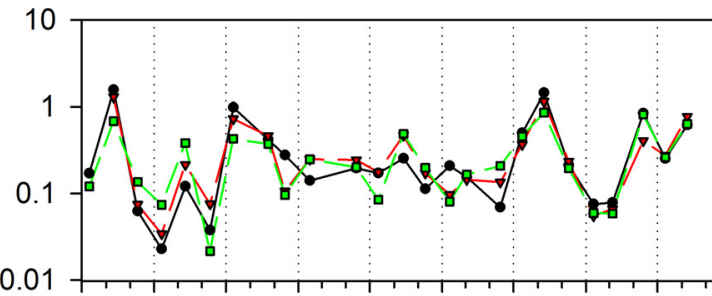

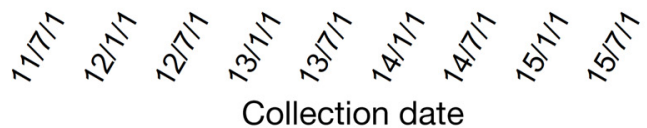

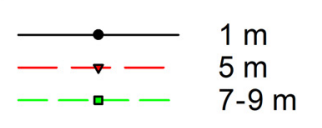

Fig. 3. Temporal variation in physical and biotic variables at 3 depths at Stn 16 in Otsuchi Bay, Japan. Dates are given as $\mathrm{yr} / \mathrm{mo} / \mathrm{d}$. Key indicates depth (m). A break in the chl a data indicates that the data are missing. VBR: virus to bacteria ratio

\subsection{Seasonal patterns of bacterial, viral, and pico- and nanophytoplankton abundances}

The means and ranges of biotic variables are summarized in Table 1. A recurring seasonal bacterial abundance pattern was found during the study pe- 
riod, with higher values occurring between May and September (Figs. 2 \& 3; Figs. S1-S3). The seasonal trend of viral abundance generally followed that of bacterial abundance, with the former being related to the latter according to the following regression: log $($ viral abundance $)=-0.637( \pm 0.030)+0.701( \pm 0.025)$ $\times \log$ (bacterial abundance) $\left( \pm \mathrm{SE}_{;} \mathrm{r}^{2}=0.65, \mathrm{p}<0.001\right.$, $\mathrm{n}=432$ ) (Fig. S4). The VBR did not exhibit a clear seasonal pattern (Figs. 2 \& 3; Figs. S1-S3) and ranged from 3.8-23.5, with a mean \pm SD of $10.8 \pm 3.6$ ( $\mathrm{n}=432$ ). The VBR histogram and dot plots displayed a moderate skewness toward larger values (skewness, 0.576), with the median and the $5^{\text {th }}$
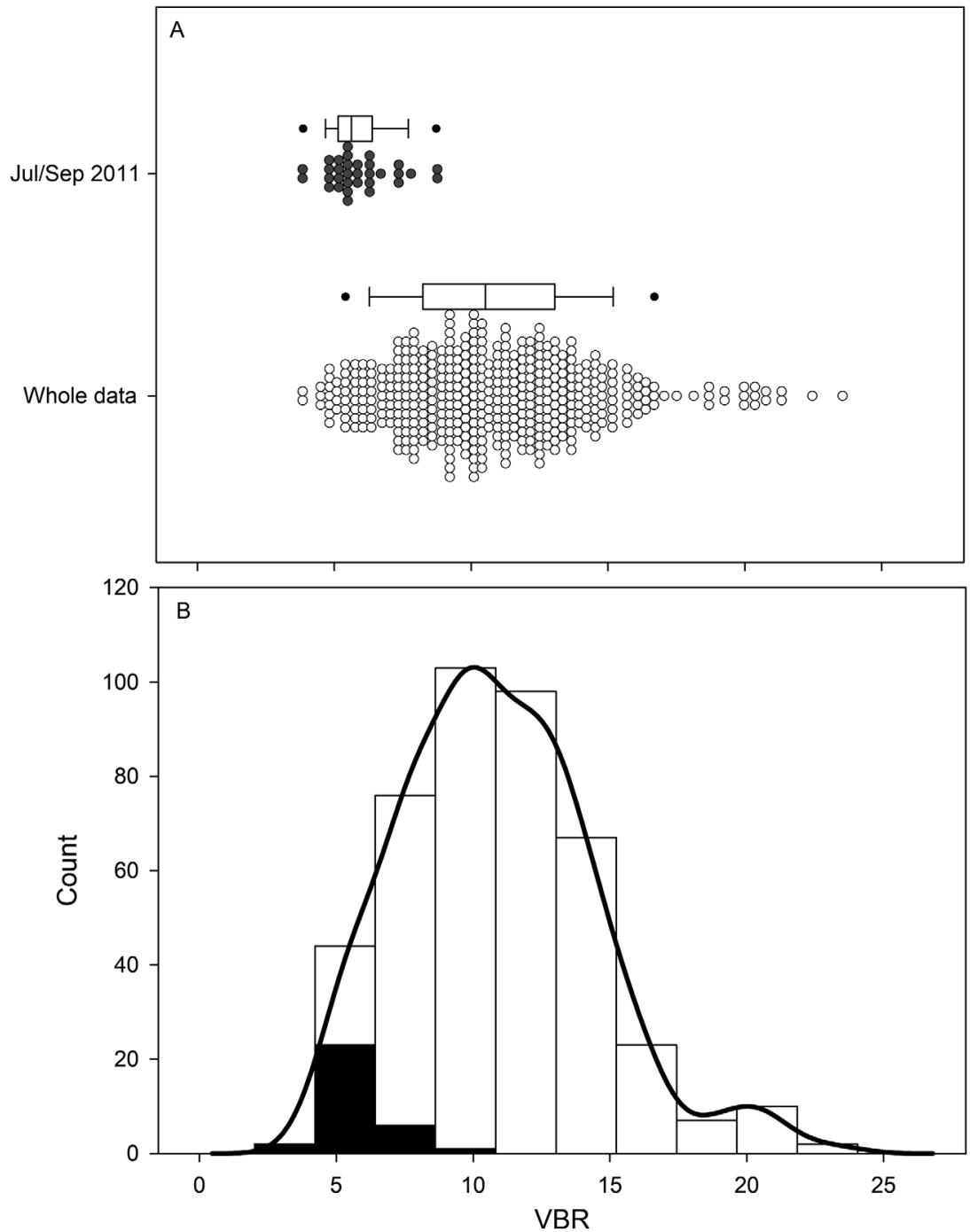

Fig. 4. (A) Dot plots for the whole virus to bacteria ratio (VBR) data and for a subset of the VBR data collected in July and September 2011. Box plots show the median values (vertical line in each box), $25^{\text {th }}$ and $75^{\text {th }}$ percentiles (box edges), $10^{\text {th }}$ and $90^{\text {th }}$ percentiles (error bars), and $5^{\text {th }}$ and $95^{\text {th }}$ percentiles (outlier plots). (B) Histograms for the whole VBR data (open bars) and for the subset of VBR data collected in July and September 2011 (closed bars). For the whole data histogram, the kernel density estimates (curved line) are also shown $95^{\text {th }}$ percentiles being 10.5 and $5.4-16.7$, respectively (Fig. 4).

The notable exception is the low VBR during the early period (July and September 2011), with a mean $\pm \mathrm{SD}$ of $5.9 \pm 1.2(\mathrm{n}=32$; Fig. 4$)$. The median value of the VBR during this period (5.6) was significantly lower than the corresponding value for the rest of the data (11.0, p $<0.001$, ANOVA on ranks). During this period, the regression equation relating viral abundance to bacterial abundance was as follows: log (viral abundance) $=-0.666( \pm 0.107)+0.569( \pm 0.081)$ $\times \log$ (bacterial abundance) $\left( \pm \mathrm{SE}_{;} \mathrm{r}^{2}=0.63, \mathrm{p}<0.001\right.$, $\mathrm{n}=32$ ) (Fig. S4). This regression line displayed a downward offset relative to the whole data regression line, with the slope being $20 \%$ smaller than that for the whole data.

The abundance peaks for picocyanobacteria, picoeukaryotes, and cryptophytes generally occurred between May and July (Figs. 2 \& 3; Figs. S1-S3), consistent with previous observations for other mid-latitude coastal environments (Li \& Dickie 2001, Tarran \& Bruun 2015). The chl a concentration varied in a complex manner, with higher values (>10 $\mu g \mathrm{l}^{-1}$ ) being observed in March. The most conspicuous spring bloom (maximum chl a concentration: $39 \mu \mathrm{g} \mathrm{l}^{-1}$ ), dominated by centric diatoms (Tachibana et al. 2017), was observed in March 2012, when Oyashio water intruded into the bay (Ishizu et al. 2017).

\subsection{Correlations}

In the whole dataset, bacterial and viral abundances were positively correlated with temperature and chl a concentration (Table 2; Fig. S5). This result is consistent with previous reports that bacterial abundance generally increases with temperature and chl a concentration (Cole et al. 1988, White et al. 1991), which may lead to higher viral abundance (Wommack \& Colwell 2000, Weinbauer 2004). This pattern is generally explained by a trophic coupling from primary producers to consumers (bacteria) toward predators (viruses). However, Spear- 
Table 2. Spearman's correlation analysis $\left(r_{s}\right)$ for the biotic and environmental variables. Values in parentheses indicate the level of significance. NS: not significant $(\mathrm{p}>0.05) . \mathrm{n}=432$, unless otherwise indicated. Plots are presented in Figs. S5 \& S6 in the Supplement

\begin{tabular}{|c|c|c|c|}
\hline & $\begin{array}{c}\text { Bacterial } \\
\text { abundance }\end{array}$ & $\begin{array}{c}\text { Viral } \\
\text { abundance }\end{array}$ & VBR \\
\hline Temperature & $0.414(<0.001)$ & $0.497(<0.001)$ & NS \\
\hline Salinity & $-0.599(<0.001)$ & $-0.462(<0.001)$ & $0.281(<0.001)$ \\
\hline Chl a concentration ${ }^{a}$ & $0.361(<0.001)$ & $0.16(<0.005)$ & $-0.388(<0.001)$ \\
\hline $\begin{array}{l}\text { Picocyanobacterial } \\
\text { abundance }\end{array}$ & $0.636(<0.001)$ & $0.626(<0.001)$ & $-0.136(<0.005)$ \\
\hline $\begin{array}{l}\text { Picoeukaryote } \\
\text { abundance }\end{array}$ & $0.700(<0.001)$ & $0.647(<0.001)$ & $-0.215(<0.001)$ \\
\hline $\begin{array}{l}\text { Cryptophyte } \\
\text { abundance }\end{array}$ & $0.571(<0.001)$ & $0.451(<0.001)$ & $-0.306(<0.001)$ \\
\hline VBR & $-0.487(<0.001)$ & NS & \\
\hline Viral abundance & $0.818(<0.001)$ & & \\
\hline
\end{tabular}

tween the VBR and temperature was not significant (Table 2; Fig. S5).

\subsection{Low VBR phenomenon in 2011}

As described above, the VBR was low during the early period of sampling (July and September 2011). We further examined the low VBR phenomenon by comparing the virusbacteria variables with those obtained during the warm season of subsequent years (Fig. 5; Table S2). There was no significant difference in the bacterial abundance between 2011 and other years, except for 2012 (Fig. 5A). In contrast, both viral abundance and the man's correlation coefficient $\left(\mathrm{r}_{\mathrm{s}}\right)$ between bacterial abundance and the abundances of pico- and nanophytoplankton groups $\left(\mathrm{r}_{\mathrm{s}}=0.636,0.700\right.$, and 0.571 for picocyanobacteria, picoeukaryotes, and cryptophytes, respectively) were much larger than that between the bacterial abundance and chl a concentration $\left(\mathrm{r}_{\mathrm{s}}=0.361\right)$ (Table 2; Figs. S5 \& S6). Viral abundance displayed the same trend, with the correlation coefficients with pico- and nanophytoplankton groups $\left(r_{s}=0.626,0.647\right.$, and 0.451 for picocyanobacteria, picoeukaryotes, and cryptophytes, respectively) being much larger than that between the viral abundance and chl a concentration $\left(\mathrm{r}_{\mathrm{s}}=0.16\right)$ (Table 2; Figs. S5 \& S6). These results indicate that the trophic coupling from primary producers to virusbacteria systems was tight during the warm season when pico- and nanophytoplankton were abundant.

Both bacterial and viral abundances as well as the VBR were low during the spring blooms in March. During a most conspicuous diatom bloom observed in March 2012, the average $( \pm$ SD) bacterial and viral abundances and the VBR were relatively low: $12( \pm 3)$ $\times 10^{5}$ cells ml ${ }^{-1}, 0.72( \pm 0.10) \times 10^{7}$ viruses $\mathrm{ml}^{-1}$, and $6.4 \pm 1.6$, respectively $(\mathrm{n}=17)$. The mechanisms underlying the low VBR during spring blooms in Otsuchi Bay need to be examined in future studies.

Bacterial and viral abundances tended to increase with decreasing salinity (Table 2; Fig. S5), which may indicate a supply of labile organic matter from rivers. The VBR was negatively correlated with the phytoplankton variables, including the concentration of chl $a$ and the pico- and nano-phytoplankton abundances, while it was positively correlated with salinity (Table 2; Figs. S5 \& S6). The correlation be-
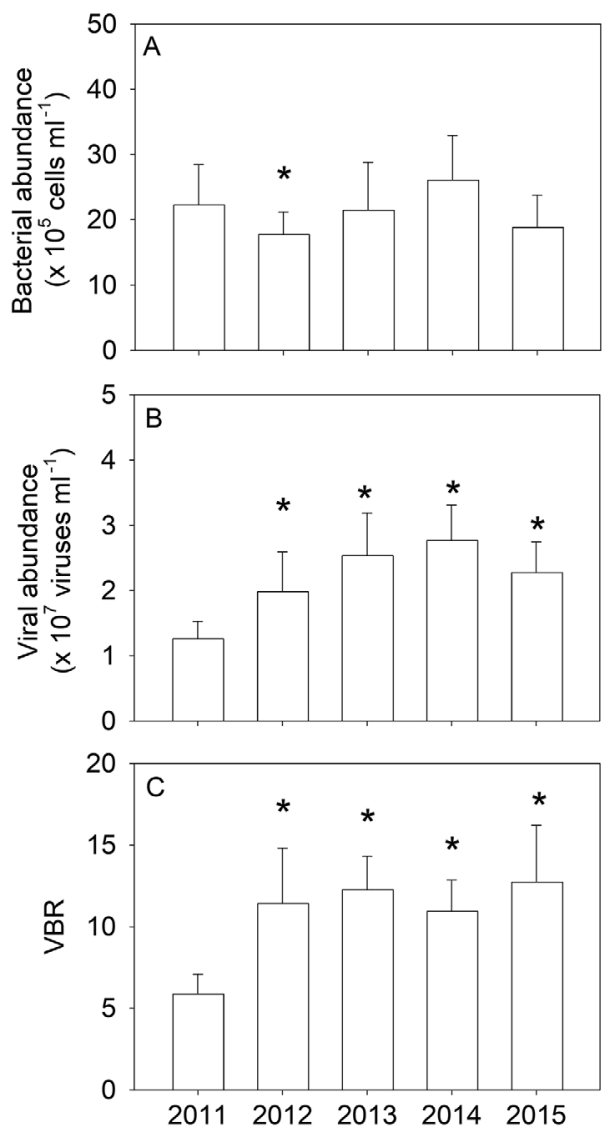

Fig. 5. Mean (A) bacterial abundance, (B) viral abundance, and $(\mathrm{C})$ virus to bacteria ratio (VBR) for the data collected in July and September between 2011 and 2015 (except for 2012 when the fall sampling was conducted in October instead of September). Errors are standard deviations. N = 18-24 for each year. Asterisks indicate significant differences between 2011 and other years $(p<0.05)$ as determined by the ANOVA on ranks. Statistical results are summarized in Table S2 
VBR in 2011 were significantly lower than those in subsequent years (Fig. 5B,C). These results suggest that the low VBR in July and September 2011 was primarily due to a significantly lower viral abundance in 2011 compared to the other years, although it was partly due to higher bacterial abundance in 2011 compared to 2012. No anomalous features in the 2011 data were observed for physical (temperature, salinity, and density) and other biotic variables (chl a concentration and the abundances of pico- and nanophytoplankton) (Table S2, Fig. S7), except for turbidity (see below).

Although the VBR values were consistently low in July and September 2011, similarly low VBR values occurred sporadically in other months and years (Figs. 2 \& 3; Figs. S2-S4). As already mentioned, relatively low VBR (around 6) was observed during spring blooms. Thus, processes driving low VBR were likely operating not only in July and September 2011, but also at other sampling times to a variable extent, and likely via different mechanisms. In the following discussion, we focus on the plausible mechanisms responsible for the low VBR during July and September 2011.

The VBR is controlled by several environmental and biological factors involved in the regulation of virus-bacteria systems (Knowles et al. 2017, Parikka et al. 2017). One hypothesis to explain low VBR in July and September 2011 is that viruses were scavenged by non-host particles generated by the earthquake and tsunami. This hypothesis is built on 2 lines of information: (1) suspended sediments can remove viruses from the water column, and (2) turbidity (particle loading) was high in July and September 2011 when the VBR was low.

(1) Hewson \& Fuhrman (2003) found that the viruses were removed by suspended sediment particles in the coastal marine environments. The removal rate increased with increasing concentrations of suspended solids, although it also depended on the location and sediment size. From the results obtained in Los Angeles Harbor (USA), they estimated that $60 \%$ of the viral standing stock is potentially removed by suspended sediments per day. Viral adsorption to sediment particles has also been examined in Arctic coastal waters influenced by melting glaciers (Maat et al. 2019a,b). Laboratory experiments revealed that cultured algal viruses and viruses in seawater were removed by adsorption to sediment particles collected in the inner fjord (Maat et al. 2019a). In the field, the VBR decreased from 10-16 in open water to 3-6 in the vicinity of glaciers, displaying a negative relationship with turbidity (Maat et al. 2019b). Simi- larly in alpine lakes, Drewes et al. (2016) found that the VBR tended to decrease with turbidity. The reduction in VBR was ascribed to viral scavenging by sediment particles (Drewes et al. 2016, Maat et al. 2019b).

(2) Fukuda et al. (2015) found that turbidity was high in Otsuchi Bay between May and September 2011. A sediment core analysis using a sample collected off Sendai Bay (160 km south of Otsuchi Bay) indicated that a strong ground motion by the earthquake and the high frictional velocity of the subsequent tsunami generated a large turbidity current immediately after the tsunami (Ikehara et al. 2014). This initial sedimentation event was followed by repeated generation of turbidity currents by aftershocks, which appeared to last over several weeks to months (Ikehara et al. 2014). Therefore, the high turbidity condition that Fukuda et al. (2015) observed 2-5 mo after the tsunami is likely a consequence of sediment resuspension caused by the aftershocks as well as prolonged riverine and atmospheric inputs of particles originating from the tsunami-derived debris and exposed soils and sediments, depending on meteorological conditions (Minghelli et al. 2019). The inputs were probably enhanced by high-intensity reconstruction activities, including the tsunamidebris removal, land elevation, and the construction of sea walls and roads.

Based on the above information, we hypothesized that high turbidity (particle loading) contributed to the low VBR. To test this hypothesis, we examined the relationship between turbidity and the VBR using the data collected in 2011 and 2012 (Fukuda et al. 2015). We used the data collected in summer to fall to minimize the influence of seasonal variability. In these data, we did not find a clear vertical trend in turbidity and VBR, which is partly explained by the fact that our data were collected mostly in shallow

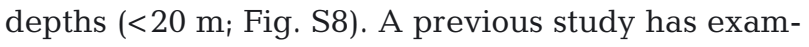
ined turbidity-VBR relationships using the distance from shore to sampling stations (Maat et al. 2019b). However, in our case, the sampling stations were mostly located inside the bay (Fig. 1), with small variability in distances between the station and the nearest shore. Therefore, we plotted the data against the distance between each station and the innermost part (the mouth of the major inflowing river) of the bay. The results showed no clear horizontal pattern, except that turbidity and VBR tended to be high and low, respectively, at the station (Stn 16) nearest to the river mouth (Fig. S8A,B). The correlation between bacterial abundance and turbidity was insignificant ( $p>0.05$ ) (Fig. 6A). In contrast, the viral abundance and VBR were significantly $(p<0.05)$ negatively cor- 

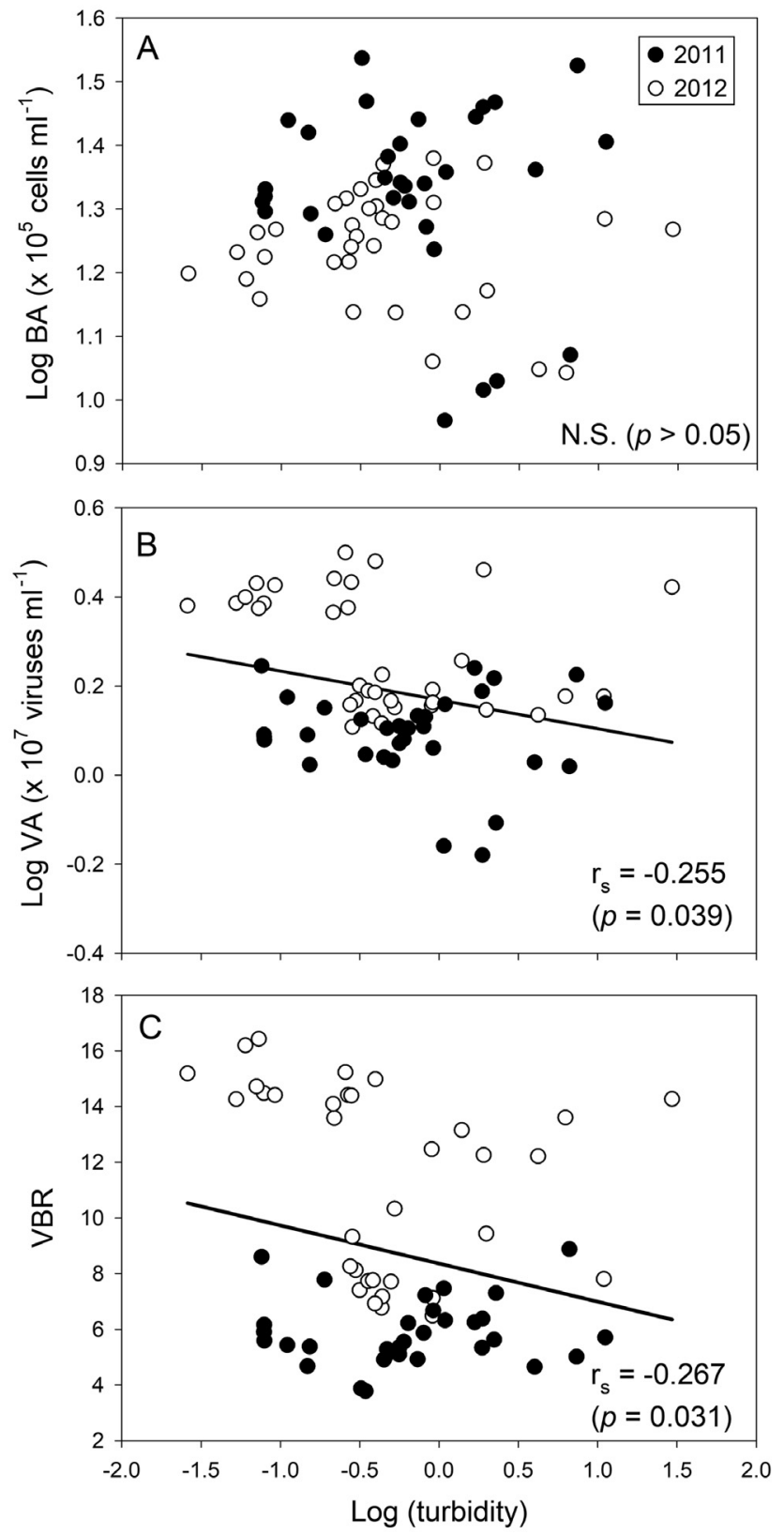

Fig. 6. Relationship between turbidity and the virus-bacteria variables, including (A) bacterial abundance (BA), (B) viral abundance (VA), and (C) the virus to bacteria ratio (VBR). Data are from the July and September samplings in 2011 (closed circles) and July and October samplings in 2012 (open circles). An ordinary least-squares regression line is added to the plots for which correlations $\left(\mathrm{r}_{\mathrm{s}}\right)$ between $x$ and $y$ variables were significant $(p<0.05)$

related with turbidity (Fig. 6B,C). These results are consistent with the hypothesis that viruses were removed via scavenging by resuspended sediments and particles from other sources, leading to a reduction in the VBR. The particles provided attachment surfaces not only for viruses but also for bacteria. The insignificant correlation between bacterial abundance and turbidity indicates that the effect of scavenging on bacteria was small. Alternatively, the resuspended sediments may enhance bacterial production via the supply of organic substrate (a positive effect) (Wainright 1987, Uchimiya et al. 2016), compensating the negative effect due to scavenging. Because viral abundance is high in marine sediments (Danovaro et al. 2008), viruses might be released from the resuspended sediments to surrounding seawater (a reverse process of viral scavenging); however, effects of scavenging appeared to surpass those of viral release, with net outcome of the sediment loading being a reduction in viral abundance and the VBR.

Increased removal of the viruses under the condition of high particle concentration (turbidity) is consistent with the theoretical prediction that virus removal by scavenging is enhanced by the increased encounter rate between the viruses and non-host particles (Murray \& Jackson 1992). However, the virus removal dynamics are not only controlled by the virus-particle encounter rate, but also by the type of viruses (Maat et al. 2019a, Yamada et al. 2020) and by particle surface characteristics (Weinbauer et al. 2009, Syngouna \& Chrysikopoulos 2010, Armanious et al. 2016, Yamada et al. 2020). Complexities in the regulation of viral scavenging by particles partly explain the broad scattering observed in the relationship between the viral abundance (or VBR) and turbidity (Fig. 6B,C).

Viruses adsorbed to organic-rich particles could be rapidly destroyed by ectoenzymes or, alternatively, proliferate upon infection of attached hosts (Weinbauer et al. 2009). For inorganic particles, adsorption to surfaces can protect the viruses to reduce the viral decay rates (Kapuscinski \& Mitchell 1980). Viruses scavenged by resuspended sediments are likely buried in the tsunami deposits, where they could persist and continue to affect the biogeochemical cycles for a long period (Cai et al. 2019). In the water column, the increase in viral abundance after the diminishment of sediment loading is explained by rapid turnover of viruses (Noble \& Fuhrman 2000).

\subsection{Concluding remarks}

We analyzed a time-series of data on bacterial and viral abundances collected in Otsuchi Bay after the mega-earthquake and huge tsunami in March 2011. Although data interpretation was compromised due to the lack of data either before or immediately after 
the tsunami, our data provided a novel insight into a long-term impact of the tsunami on the virus-bacteria system in Otsuchi Bay. During the initial period of sampling (July and September 2011), the average VBR was $5.9 \pm 1.2( \pm \mathrm{SD})$, which was substantially lower than the average VBR for the whole data set $(10.8 \pm 3.6)$. During the warm seasons of 2011 and 2012, the viral abundance and the VBR decreased along with an increase in turbidity. These results suggest that the virus-bacteria dynamics were disturbed by viral scavenging due to resuspended sediments and other particles discharged from the catchment to the bay. Given that the tsunami extensively caused high turbidity along the coast of the damaged area (Ikehara et al. 2014, Minghelli et al. 2019), the disturbance of virus-bacteria dynamics was likely widespread and exerted far-reaching impacts on the functioning of the coastal ecosystem. One possibility is the suppression of nutrient regeneration driven by viruses (Wilhelm \& Suttle 1999, Shelford et al. 2012), which may lead to a reduction in primary production supported by the regenerated nitrogen (Shiozaki et al. 2020). Furthermore, viruses removed from the water column were buried in the tsunami deposits, where they could persist and continue to affect the biogeochemical cycles.

Acknowledgements. We thank Takeshi Miki, Yosuke Yamada, and Chiaki Motegi for valuable comments on the manuscript, and the staff of International Coastal Research Center, Masataka Kurosawa, Masaaki Hirano, Takanori Suzuki, and Nobuhiko Iwama, for help during field sampling. This study was supported by the research program 'Tohoku Ecosystem-Associated Marine Sciences (TEAMS)' of the Ministry of Education, Culture, Sports, Science and Technology, Japan, and JSPS KAKENHI Grant Numbers JP19H05667, JP17H06294, and JP21H03586.

\section{LITERATURE CITED}

Armanious A, Aeppli M, Jacak R, Refardt D, Sigstam T, Kohn T, Sander M (2016) Viruses at solid-water interfaces: a systematic assessment of interactions driving adsorption. Environ Sci Technol 50:732-743

* Brussaard CP (2004) Optimization of procedures for counting viruses by flow cytometry. Appl Environ Microbiol 70:1506-1513

Cai L, Jorgensen BB, Suttle CA, He M, Cragg BA, Jiao N, Zhang R (2019) Active and diverse viruses persist in the deep sub-seafloor sediments over thousands of years. ISME J 13:1857-1864

Cole JJ, Findlay S, Pace ML (1988) Bacterial production in fresh and saltwater ecosystems: a cross-system overview. Mar Ecol Prog Ser 43:1-10

* Danovaro R, Corinaldesi C, Filippini M, Fischer UR and others (2008) Viriobenthos in freshwater and marine sediments: a review. Freshw Biol 53:1186-1213

Drewes F, Peter H, Sommaruga R (2016) Are viruses impor- tant in the plankton of highly turbid glacier-fed lakes? Sci Rep 6:24608

*Finke JF, Hunt BPV, Winter C, Carmack EC, Suttle CA (2017) Nutrients and other environmental factors influence virus abundances across oxic and hypoxic marine environments. Viruses 9:152

FFukuda H, Katayama R, Yang Y, Takasu H, Nishibe Y, Tsuda A, Nagata T (2015) Nutrient status of Otsuchi Bay (northeastern Japan) following the 2011 off the Pacific coast of Tohoku Earthquake. J Oceanogr 72:39-52

Fukuda H, Yang Y, Takasu H, Nishibe Y, Tachibana A, Tsuda A, Nagta T (2017) Nutrient status of Otsuchi Bay on the Sanriku Coast of Japan: 5 years after the 2011 off the Pacific Coast of Tohoku Earthquake. Bull Coast Oceanogr 54:105-116 (in Japanese)

Goto K, Ishizawa T, Ebina Y, Imamura F, Sato S, Udo K (2021) Ten years after the 2011 Tohoku-oki earthquake and tsunami: geological and environmental effects and implications for disaster policy changes. Earth Sci Rev 212:103417

KHamaoka H, Kamiyama T, Hori M (2020) Estimating the change in regional scale distribution of seagrass and macroalgal beds using discrete local distribution data analyzed from aerial images. Ecol Res 35:76-94

*Hewson I, Fuhrman JA (2003) Viriobenthos production and virioplankton sorptive scavenging by suspended sediment particles in coastal and pelagic waters. Microb Ecol 46:337-347

Ikehara K, Irino T, Usami K, Jenkins R, Omura A, Ashi J (2014) Possible submarine tsunami deposits on the outer shelf of Sendai Bay, Japan resulting from the 2011 earthquake and tsunami off the Pacific coast of Tohoku. Mar Geol 358:120-127

* Ishizu M, Itoh S, Tanaka K, Komatsu K (2017) Influence of the Oyashio Current and Tsugaru Warm Current on the circulation and water properties of Otsuchi Bay, Japan. J Oceanogr 73:115-131

Kapuscinski RB, Mitchell R (1980) Processes controlling virus inactivation in coastal waters. Water Res 14:363-371

* Knowles B, Bailey B, Boling L, Breitbart M and others (2017) Variability and host density independence in inductionsbased estimates of environmental lysogeny. Nat Microbiol 2:17064

Komatsu T, Ohtaki T, Sakamoto S, Sawayama S and others (2015) Impact of the 2011 tsunami on seagrass and seaweed beds in Otsuchi Bay, Sanriku Coast, Japan. In: Ceccaldi HJ, Hénocque Y, Koike Y, Komatsu T, Stora G, Tusseau-Vuillemin MH (eds) Marine productivity: perturbations and resilience of socio-ecosystems. Springer. Cham, p 43-53

Li WK, Dickie PM (2001) Monitoring phytoplankton, bacterioplankton, and virioplankton in a coastal inlet (Bedford Basin) by flow cytometry. Cytometry 44:236-246

Maat DS, Prins MA, Brussaard CPD (2019a) Sediments from Arctic tide-water glaciers remove coastal marine viruses and delay host infection. Viruses 11:123

Maat DS, Visser RJW, Brussaard CPD (2019b) Virus removal by glacier-derived suspended fine sediment in the Arctic. J Exp Mar Biol Ecol 521:151227

Marie D, Partensky F, Vaulot D, Brussaard C (1999) Enumeration of phytoplankton, bacteria, and viruses in marine samples. Curr Protoc Cytom 10:11.11.11-11.11.15

* Marie D, Rigaut-Jalabert F, Vaulot D (2014) An improved protocol for flow cytometry analysis of phytoplankton cultures and natural samples. Cytometry A 85:962-968 
Minghelli A, Lei M, Charmasson S, Rey V, Chami M (2019) Monitoring suspended particle matter using GOCI satellite data after the Tohoku (Japan) Tsunami in 2011. ISEE J Sel Top Appl Earth Observ Remote Sens 12:567-576

Muraoka D, Tamaki H, Takami H, Kurita Y, Kawamura T (2017) Effects of the 2011 Great East Japan Earthquake and tsunami on two kelp bed communities on the Sanriku coast. Fish Oceanogr 26:128-140

Murray AG, Jackson GA (1992) Viral dynamics: a model of the effects of size, shape, motion and abundance of single-celled planktonic organisms and other particles. Mar Ecol Prog Ser 89:103-116

Nishibe Y, Isami H, Fukuda H, Nishida S, Nagata T, Tachibana A, Tsuda A (2016) Impact of the 2011 Tohoku earthquake tsunami on zooplankton community in Otsuchi Bay, northeastern Japan. J Oceanogr 72:77-90

Noble RT, Fuhrman JA (2000) Rapid virus production and removal as measured with fluorescently labeled viruses as tracers. Appl Environ Microbiol 66:3790-3797

Otobe H, Onishi H, Inada M, Michida Y, Terazaki M (2009) Estimation of water circulation in Otsuchi Bay, Japan inferred from ADCP observation. Coast Mar Sci 33:78-86

Parikka KJ, Le Romancer M, Wauters N, Jacquet S (2017) Deciphering the virus-to-prokaryote ratio (VPR): insights into virus-host relationships in a variety of ecosystems. Biol Rev Camb Philos Soc 92:1081-1100

Seike K, Shirai K, Kogure Y (2013) Disturbance of shallow marine soft-bottom environments and megabenthos assemblages by a huge tsunami induced by the 2011 M9.0 Tohoku-Oki earthquake. PLOS ONE 8:e65417

Shelford EJ, Middelboe M, Møller EF, Suttle CA (2012) Virus-driven nitrogen cycling enhances phytoplankton growth. Aquat Microb Ecol 66:41-46

Shiozaki T, Tada Y, Fukuda H, Furuya K, Nagata T (2020) Primary production and nitrogen assimilation rates from bay to offshore waters in the Oyashio-Kuroshio-Tsugaru Warm Current interfrontal region of the northwestern north Pacific Ocean. Deep Sea Res I 164:103304

Steward GF, Culley AI, Mueller JA, Wood-Charlson EM, Belcaid M, Poisson G (2013) Are we missing half of the viruses in the ocean? ISME J 7:672-679

Suttle CA (2007) Marine viruses - major players in the global ecosystem. Nat Rev Microbiol 5:801-812

Syngouna VI, Chrysikopoulos CV (2010) Interaction between viruses and clays in static and dynamic batch systems. Environ Sci Technol 44:4539-4544

Tachibana A, Nishibe Y, Fukuda H, Kawanobe K, Tsuda A (2017) Phytoplankton community structure in Otsuchi Bay, northeastern Japan, after the 2011 off the Pacific coast

Editorial responsibility: Curtis Suttle,

Vancouver, British Columbia, Canada

Reviewed by: D. Maat, L. Cai and 1 anonymous referee of Tohoku Earthquake and tsunami. J Oceanogr 73: 55-65

*Tarran GA, Bruun JT (2015) Nanoplankton and picoplankton in the Western English Channel: abundance and seasonality from 2007-2013. Prog Oceanogr 137:446-455

* Tomaru Y, Nagasaki K (2007) Flow cytometric detection and enumeration of DNA and RNA viruses infecting marine eukaryotic microalgae. J Oceanogr 63:215-221

*Uchimiya M, Motegi C, Nishino S, Kawaguchi Y, Inoue J, Ogawa H, Nagata T (2016) Coupled response of bacterial production to a wind-induced fall phytoplankton bloom and sediment resuspension in the Chukchi Sea Shelf, Western Arctic Ocean. Front Mar Sci 3:231

Wainright SC (1987) Stimulation of heterotrophic microplankton production by resuspended marine sediments. Science 238:1710-1712

WWeinbauer MG (2004) Ecology of prokaryotic viruses. FEMS Microbiol Rev 28:127-181

Weinbauer MG, Bettarel Y, Cattaneo R, Luef B and others (2009) Viral ecology of organic and inorganic particles in aquatic systems: avenues for further research. Aquat Microb Ecol 57:321-341

White PA, Kalff J, Rasmussen JB, Gasol JM (1991) The effect of temperature and algal biomass on bacterial production and specific growth rate in freshwater and marine habitats. Microb Ecol 21:99-118

*wigington CH, Sonderegger D, Brussaard CPD, Buchan A and others (2016) Re-examination of the relationship between marine virus and microbial cell abundances. Nat Microbiol 1:15024

W Wilhelm SW, Suttle CA (1999) Viruses and nutrient cycles in the sea: viruses play critical roles in the structure and function of aquatic food webs. Bioscience 49:781-788

* Winget DM, Helton RR, Williamson KE, Bench SR, Williamson SJ, Wommack KE (2011) Repeating patterns of virioplankton production within an estuarine ecosystem. Proc Natl Acad Sci USA 108:11506-11511

*Wommack KE, Colwell RR (2000) Virioplankton: viruses in aquatic ecosystems. Microbiol Mol Biol Rev 64:69-114

* Yamada Y, Guillemette R, Baudoux AC, Patel N, Azam F (2020) Viral attachment to biotic and abiotic surfaces in seawater. Appl Environ Microbiol 86:e01687-19

* Yang Y, Motegi C, Yokokawa T, Nagata T (2010) Largescale distribution patterns of virioplankton in the upper ocean. Aquat Microb Ecol 60:233-246

* Zimmerman AE, Howard-Varona C, Needham DM, John SG and others (2020) Metabolic and biogeochemical consequences of viral infection in aquatic ecosystems. Nat Rev Microbiol 18:21-34

Submitted: July 12, 2021

Accepted: October 7, 2021

Proofs received from author(s): January 28, 2022 